\title{
Descending necrotizing mediastinitis: A 10-year surgical experience in a single institution
}

\author{
Ke-Cheng Chen, MD, ${ }^{a}$ Jin-Shing Chen, MD, PhD, ${ }^{a}$ Shuenn-Wen Kuo, MD, ${ }^{a}$ Pei-Ming Huang, MD, ${ }^{a}$ \\ Hsao-Hsun Hsu, MD, ${ }^{a}$ Jang-Ming Lee, MD, PhD, and Yung-Chie Lee, MD, PhD ${ }^{a}$
}

Objective: Early diagnosis and aggressive surgical drainage are very important for successful treatment of descending necrotizing mediastinitis. However, the surgical techniques used for this condition remain controversial. We report our 10-year experience of managing this devastating disease, focusing on the multidisciplinary, minimally invasive operative procedures and the unique bacteriologic factors in Taiwan.

Methods: Between January 1997 and January 2007, we retrospectively reviewed 18 patients with descending necrotizing mediastinitis who were treated in the National Taiwan University Hospital. Diagnosis and Endo classification were confirmed by computed tomography of the neck and chest.

Results: Eight women and 10 men were included in this study. The mean age was 57.8 \pm 15.2 years. Cervical drainage was performed in the involved area in all patients. The methods for mediastinal drainage included transcervical $(\mathrm{n}=10)$, video-assisted thoracic surgical drainage $(n=6)$, subxiphoid drainage $(n=1)$, and mediastinoscopy-assisted drainage $(\mathrm{n}=1)$. We could not rescue 3 patients because of uncontrolled sepsis before surgery, for a mortality rate of $16.7 \%$. Klebsiella pneumoniae uniquely represents the most common pathogen in diabetic patients $(P=.01)$, leading to more complicated courses in older patients $(P=.04)$ and requiring more surgical interventions $(P=.05)$ than other pathogens.

Conclusion: Transcervical mediastinal drainage is first justified in patients with limited disease in the upper mediastinum. For those with involvement of the lower anterior mediastinum, an additional subxiphoid approach is suggested. Cervicotomy with video-assissted mediastinal drainage is an excellent combination for involvement of the posterior mediastinum and pleural space. Klebsiella pneumoniae uniquely represents the most important and threatening causative pathogen for diabetic patients with descending necrotizing mediastinitis.

From the Departments of Surgery and Traumatology, ${ }^{\mathrm{a}}$ National Taiwan University Hospital and National Taiwan University College of Medicine, Taipei, Taiwan.

Received for publication Aug 24, 2007; revisions received Jan 2, 2008; accepted for publication Jan 5, 2008.

Address for reprints: Yung-Chie Lee, MD, $\mathrm{PhD}, 6 \mathrm{~F}-1$, 99, Section 3, Roosevelt Rd, Taipei 10646,Taiwan (E-mail: damu@ha.mc. ntu.edu.tw).

J Thorac Cardiovasc Surg 2008;136:191-8 $0022-5223 / \$ 34.00$

Copyright $\odot 2008$ by The American Association for Thoracic Surgery

doi:10.1016/j.jtcvs.2008.01.009
A cute mediastinitis is a serious infection involving the connective tissue that fills the interpleural spaces and surrounds the median thoracic organs. The most common causes of mediastinitis are esophageal perforations and infection after operations through sternotomy incisions. One of the most dreaded and lethal forms of mediastinitis is descending necrotizing mediastinitis (DNM), which is referred to as a diffuse necrotizing variety that occurs as a complication of odontogenic or cervicofascial infections spreading along the deep fascial planes into the mediastinum. ${ }^{1,2}$ As infection spreads along these planes, widespread cellulitis, necrosis, abscess formation, and sepsis may occur through a fulminant course. Delay of diagnosis and delayed or incomplete drainage of the mediastinum are the main causes for the high mortality rate in this life-threatening condition. ${ }^{3-14}$ Even with the use of computed tomographic (CT) scanning, aggressive drainage, and modern antibiotic treatment, the mortality rate of DNM remains high. ${ }^{2,4,14}$ Surgical management, particularly the optimal form of mediastinal drainage, remains controversial. Many investigators have recommended the advantages of invasive procedures, including median sternotomy, clamshell incisions, and routine thoracotomy. ${ }^{4,9,14-16}$ However, these 


\section{Abbreviations and Acronyms \\ $\mathrm{CT}=$ computed tomography \\ DNM $=$ descending necrotizing mediastinitis \\ VATS $=$ video-assisted thoracic surgery}

invasive methods may lead to unexpected results, such as massive tissue injury, osteomyelitis, dehiscence of the sternum, and other complications. ${ }^{12,15,16}$

We report our 10-year surgical experience with 18 patients affected by DNM, focusing on the application of multidisciplinary, minimally invasive procedures according to the extent of disease. The unique bacteriologic characteristics in Taiwanese patients with DNM are also discussed.

\section{Patients and Methods}

Between January 1997 and January 2007, we retrospectively reviewed the case histories of 18 patients with DNM who were hospitalized and treated in the Division of Thoracic Surgery, Department of Surgery and Traumatology, National Taiwan University Hospital. The medical charts, including personal demographics, image studies, operative records, hospital course, morbidity, and mortality were carefully reviewed. In all cases, the criteria of Estrera and colleagues $^{2}$ were fulfilled, including (1) clinical manifestation of severe oropharyngeal infection, (2) demonstration of characteristic radiographic features of mediastinitis, (3) documentation of necrotizing mediastinal infection at operation or postmortem examination, and (4) establishment of a relationship between oropharyngeal infection and development of the necrotizing mediastinal process. In each case, this relationship was clearly established. Specifically excluded from this study were patients with mediastinitis resulting from an esophageal perforation, because the diagnosis, treatment, and outcomes in this subset of patients are fundamentally different and widely studied.

In all cases, diffuse painful neck swelling was clinically obvious, and respiratory insufficiency with sepsis ensued, suggestive of mediastinitis. All patients received empirical broad-spectrum intravenous antibiotics as soon as the diagnosis was suspected. Once the causative pathogen was cultured, the antibiotics were adjusted according to the sensitivity test. Diagnosis was confirmed by cervicothoracic CT on an emergency basis, which showed neck infection with soft tissue infiltration and edema of muscle tissues, as well as downward involvement of the mediastinum. The patients were evaluated according to Endo and colleagues' classification ${ }^{5}$ classification of the degree of diffusion of DNM based on CT findings: in type I, the infection is localized in the upper mediastinum above the carina; in type IIA, it extends to the lower anterior mediastinum; and in type IIB, it extends to the lower anterior and posterior portions of the mediastinum (Figure 1).

The surgical management consisted of cervical and mediastinal drainage. The neck was approached through an incision anterior to the sternocleidomastoid muscle in the involved side(s). The involved cervical spaces were opened, drained, and debrided of necrotic tissue. Several procedures are available for mediastinal drainage, including transcervical mediastinal drainage, mediastinoscopyassisted drainage, video-assisted thoracic surgery (VATS) drainage, and subxiphoid drainage. The method selected depends on the Endo classification. ${ }^{5}$ Each procedure involved radical surgical debridement of the mediastinum and pleura with complete excision and
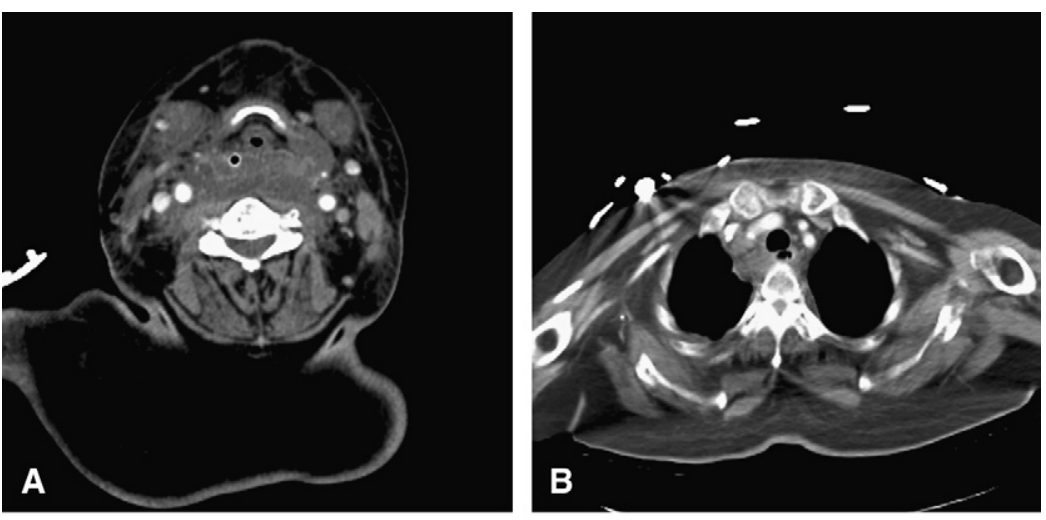

Figure 1. In case 16, the cervicothoracic CT scan revealed retropharyngeal and parapharyngeal abscess $(A)$, descending into the upper mediastinum (B) and the posterior mediastinum with bilateral thoracic empyema (C and D).
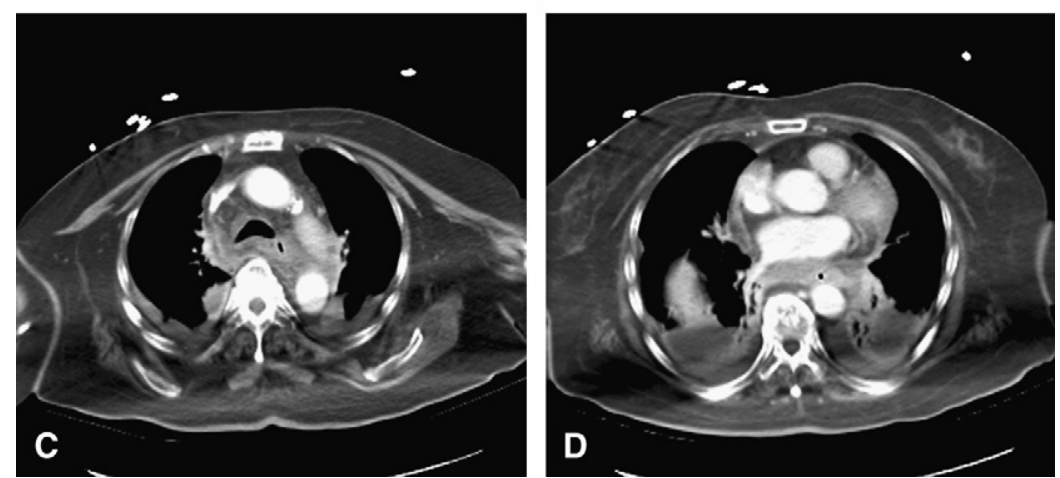

192 The Journal of Thoracic and Cardiovascular Surgery • July 2008 
decortication of necrotic tissue and adequate placement of silicone drains or chest tubes (Argyle 28 or 32; Sherwood Medical Company, St Louis, Mo) for drainage. The abscess and necrotic tissue from the deep neck area and mediastinum were sent for bacterial cultures intraoperatively. After primary surgery, follow-up CT scanning was performed in the surgical intensive care unit to assess the adequacy of therapy if clinical improvement was not obvious. Once residual abscess or necrotic tissue was detected, reoperation was immediately performed without hesitation. Repeated drainage was common owing to the progressive nature and great toxicity of DNM. ${ }^{6,9,11,12}$ The duration of drainage depended on clinical progress, return to normal CT scanning, and negative results of the cultures of fluids aspirated from the drainage tubes. We did not use routine irrigation of the mediastinum for fear of contamination and because there is not enough scientific evidence supporting this approach. We consider irrigation to be an optional method on the basis of qualitative evaluation of the material drained by the chest tubes.

\section{Results}

Our study comprises 8 women and 10 men. The characteristics, bacteriologic features, treatment course, and outcome of the patients with DNM are listed in Table 1. The mean age was $58.4 \pm 15.1$ years, ranging from 16 to 78 years. The foci of the inciting infections were retropharyngeal abscess in $5(27.8 \%)$ patients, peritonsillar abscess in 4 (22.2\%), odontogenic abscess in $3(16.7 \%)$, acute epiglottis in $3(16.7 \%)$, foreign body in $2(11.1 \%)$, and thermodilution catheter infection (Swan-Ganz; Edwards LifeSciences, Irvine, Calif) in $1(5.6 \%)$. Fourteen $(77.8 \%)$ patients had prior systemic diseases, including diabetes mellitus $(\mathrm{n}=11$, $61.1 \%)$, hypertension $(\mathrm{n}=8,44.4 \%)$, liver cirrhosis $(\mathrm{n}=2$, $11.1 \%)$, and coronary artery disease $(n=2,11.1 \%)$. The delay between onset of the primary infection and operation varied from 1 to 8 days (mean, 2.7 days). Eleven (61.1\%) patients were in Endo class I, 1 (5.6\%) in Endo class IIA, and $6(33.3 \%)$ in IIB.

\section{Operative Management}

All patients underwent cervicotomy for radical debridement. Among the 11 patients in Endo class I, 10 underwent transcervical mediastinal drainage and 1 received mediastinoscopyassisted drainage. For the only patient in Endo class IIA, subxiphoid drainage was performed. All 6 patients in Endo class IIB underwent VATS mediastinal drainage. Seven (38.9\%) patients underwent reoperation for postoperative CT showing residual abscess and necrotic tissue, including 2 patients undergoing a third operation. VATS reoperation was used in 4 patients, including 3 patients with type I disease who had primary transcervical drainage and 1 who had primary VATS drainage. Recervicotomy was performed in 5 patients, and tracheostomy was performed in $10(55.6 \%)$ patients.

\section{Clinical Outcome}

The outcome was favorable in $15(83.3 \%)$ patients, but 3 patients were not rescued, for a mortality rate of $16.7 \%$.
The mean hospital stay was $40.1 \pm 23.3$ days (range, 9-90 days), and their mean intensive care unit stay was $14.6 \pm$ 13.4 days (range, 1-41 days). Neither intraoperative death nor immediate postoperative death occurred. The 3 patients who died included 2 patients with significant comorbidity (both having diabetes mellitus and liver cirrhosis) and 1 with old age ( $>75$ years old). Hospitalization time was marked in all 3 (4, 4, and 8 days), and sepsis was evident before the operation. Although immediate surgery was performed (including transcervical mediastinal drainage in 2 and VATS drainage in 1), sepsis with multiple organ failure still occurred.

\section{Bacteriology}

Bacteriologic results from intraoperative samples obtained from the neck and mediastinum showed positive culture results in $14(77.8 \%)$ patients, including polymicrobial infection in $5(35.7 \%)$ and monopathogen in $9(64.3 \%)$ patients. The most common pathogen was Klebsiella pneumonia, found in $6(42.9 \%)$ patients, followed by viridans streptococci in $4(28.6 \%)$ patients. Compared with non-Klebsiella DNM $(\mathrm{n}=8)$, Klebsiella DNM $(\mathrm{n}=6)$ occurred in significantly older patients $(P=.04$ by the Student $t$ test) with a higher prevalence of diabetes mellitus $(P=.01$ by the Fisher exact test) and a higher rate of reoperation or mortality $(P=.05$ by the Fisher exact test) (Table 2).

\section{Discussion}

Nowadays, acute mediastinitis resulting from primary oropharyngeal or odontogenic infection is rare in Western countries. It is more common in developing countries owing to the poor economic conditions and consequent lack of medical resources for prevention and treatment of dental and oropharyngeal diseases. Reports indicate that this lethal complication will develop in about $2.6 \%$ of patients with deep neck infection in Taiwan. ${ }^{17,18}$ Our institution treated 18 patients in a period of 10 years, which indicated the incidence is not rare. During the past 50 years, efforts to reduce the mortality rate associated with DNM have been only moderately successful. In the first modern series of patients with DNM published in 1938, Pearse ${ }^{1}$ reported that $49 \%$ of patients died during their treatment. However, despite the subsequent introduction of intravenous antibiotics, vast improvements in anesthesia and critical care, and the development of CT imaging, the frequency of death for patients with DNM reported in the literature over the past 3 decades has remained high in the antibiotic era. ${ }^{2,4,14}$

Delay in diagnosis is the main reason for the high mortality rate in DNM because it usually runs a fulminant course. ${ }^{3-14}$ Contiguous cervicothoracic CT scan immediately confirms the diagnosis with high accuracy, showing soft tissue infiltration with loss of the normal fat planes or collection of fluid density with or without the presence of gas bubbles. It demonstrates the continuity of the infectious process between the 
TABLE 1. Characteristics, treatment course, and outcome of the patients with DNM

\begin{tabular}{|c|c|c|c|c|c|c|c|c|c|}
\hline \multicolumn{2}{|c|}{ No. Age/sex } & \multirow{2}{*}{$\begin{array}{c}\begin{array}{r}\text { Systemic } \\
\text { diseases }\end{array} \\
\text { None }\end{array}$} & \multirow{2}{*}{$\begin{array}{c}\text { Etiology } \\
\begin{array}{c}\text { Odontogenic } \\
\text { abscess }\end{array}\end{array}$} & \multirow{2}{*}{$\begin{array}{c}\begin{array}{c}\text { Endo } \\
\text { class }\end{array} \\
1\end{array}$} & \multirow{2}{*}{$\begin{array}{c}\text { Bacteriology } \\
\text { Group F and } \\
\text { viridans } \\
\text { streptococci }\end{array}$} & \multirow{2}{*}{\begin{tabular}{c}
\multicolumn{1}{c}{$\begin{array}{c}\text { Surgical } \\
\text { treatment }\end{array}$} \\
B cervicotomy and \\
transcervical \\
mediastinal \\
drainage
\end{tabular}} & \multirow{2}{*}{$\begin{array}{c}\text { Reoperation } \\
\text { None }\end{array}$} & \multirow{2}{*}{$\begin{array}{c}\begin{array}{c}\text { ICU } \\
\text { stay (d) }\end{array} \\
1\end{array}$} & \multirow{2}{*}{$\begin{array}{c}\text { Outcome } \\
\begin{array}{c}\text { Discharge } \\
\text { on POD } 22\end{array}\end{array}$} \\
\hline 1 & $34 / \mathrm{M}$ & & & & & & & & \\
\hline 2 & $63 / \mathrm{F}$ & $\mathrm{DM}$ & $\begin{array}{c}\text { Peritonsillar } \\
\text { abscess }\end{array}$ & 1 & $\begin{array}{l}\text { Klebsiella } \\
\text { pneumonia }\end{array}$ & $\begin{array}{l}\text { L cervicotomy and } \\
\text { transcervical } \\
\text { mediastinal } \\
\text { drainage }\end{array}$ & None & 15 & $\begin{array}{l}\text { Discharge } \\
\text { on POD } 63\end{array}$ \\
\hline 3 & $48 / \mathrm{M}$ & None & Foreign body & I & $\begin{array}{l}\text { Prevotella } \\
\text { species, } \\
\text { peptostreptococci }\end{array}$ & $\begin{array}{l}\text { B cervicotomy and } \\
\text { transcervical } \\
\text { mediastinal } \\
\text { drainage }\end{array}$ & None & 4 & $\begin{array}{l}\text { Discharge } \\
\text { on POD } 36\end{array}$ \\
\hline 4 & $50 / \mathrm{M}$ & None & Foreign body & I & $\begin{array}{r}\text { Streptococcus } \\
\text { constellatus }\end{array}$ & $\begin{array}{l}\text { B cervicotomy and } \\
\text { transcervical } \\
\text { mediastinal } \\
\text { drainage }\end{array}$ & None & 3 & $\begin{array}{l}\text { Discharge } \\
\text { on POD } 39\end{array}$ \\
\hline 5 & $56 / M$ & HTN & $\begin{array}{l}\text { Peritonsillar } \\
\text { abscess }\end{array}$ & 1 & None & $\begin{array}{l}\text { R cervicotomy and } \\
\text { transcervical } \\
\text { mediastinal } \\
\text { drainage }\end{array}$ & None & 1 & $\begin{array}{l}\text { Discharge } \\
\text { on POD } 28\end{array}$ \\
\hline 6 & $65 / M$ & $\mathrm{DM}$ & $\begin{array}{c}\text { Peritonsillar } \\
\text { abscess }\end{array}$ & $\| A$ & $\begin{array}{l}\text { Klebsiella } \\
\text { pneumonia }\end{array}$ & $\begin{array}{l}\text { L cervicotomy and } \\
\text { subxiphoid } \\
\text { drainage }\end{array}$ & Cervicotomy & 3 & $\begin{array}{l}\text { Discharge } \\
\text { on POD } 15\end{array}$ \\
\hline 7 & $57 / F$ & $\begin{array}{r}\text { DM, HTN, } \\
\text { LC, PUD }\end{array}$ & Acute epiglottis & 1 & $\begin{array}{l}\text { Klebsiella } \\
\text { pneumonia }\end{array}$ & $\begin{array}{l}\text { L cervicotomy and } \\
\text { transcervical } \\
\text { mediastinal } \\
\text { drainage }\end{array}$ & B VATS & 22 & $\begin{array}{l}\text { Death } \\
\quad \text { on POD } 22\end{array}$ \\
\hline 8 & $65 / F$ & $\begin{array}{r}\text { DM, LC, } \\
\text { HCC }\end{array}$ & $\begin{array}{l}\text { Odontogenic } \\
\text { abscess }\end{array}$ & IIB & $\begin{array}{l}\text { Klebsiella } \\
\text { pneumonia }\end{array}$ & $\begin{array}{l}\mathrm{L} \text { cervicotomy } \\
\text { and B VATS }\end{array}$ & None & 9 & Death on POD 9 \\
\hline 9 & $78 / F$ & DM & $\begin{array}{l}\text { Retropharyngeal } \\
\text { abscess }\end{array}$ & I & $\begin{array}{l}\text { Viridans } \\
\text { streptococci }\end{array}$ & $\begin{array}{l}\text { B cervicotomy and } \\
\text { transcervical mediastinal } \\
\text { drainage }\end{array}$ & $\begin{array}{l}\text { 2nd OP: B VATS } \\
\text { 3rd OP: B } \\
\text { cervicotomy } \\
\text { and B } \\
\text { thoracotomy }\end{array}$ & 30 & $\begin{array}{l}\text { Death on } \\
\text { POD } 30\end{array}$ \\
\hline 10 & $50 / \mathrm{M}$ & DM, HTN, CRI & $\begin{array}{l}\text { Retropharyngeal } \\
\text { abscess }\end{array}$ & I & $\begin{array}{l}\beta \text {-Hemolytic } \\
\text { streptococci }\end{array}$ & $\begin{array}{l}\text { B cervicotomy and } \\
\text { mediastinoscopic } \\
\text { mediastinal } \\
\text { debridement }\end{array}$ & None & 5 & $\begin{array}{l}\text { Discharge on } \\
\text { POD } 23\end{array}$ \\
\hline 11 & $16 / \mathrm{M}$ & None & Acute epiglottis & IIB & $\begin{array}{l}\text { Viridans } \\
\text { streptococci }\end{array}$ & $\begin{array}{l}\mathrm{R} \text { cervicotomy } \\
\text { and B VATS }\end{array}$ & None & 6 & $\begin{array}{l}\text { Discharge on } \\
\text { POD } 30\end{array}$ \\
\hline 12 & $78 / F$ & $\begin{array}{c}\text { DM, HTN, CAD, } \\
\text { CVA, PUD }\end{array}$ & $\begin{array}{l}\text { Retropharyngeal } \\
\text { abscess }\end{array}$ & 1 & None & $\begin{array}{l}\text { L cervicotomy and } \\
\text { transcervical } \\
\text { mediastinal } \\
\text { drainage }\end{array}$ & None & 13 & $\begin{array}{l}\text { Discharge on } \\
\text { POD } 32\end{array}$ \\
\hline 13 & $52 / \mathrm{M}$ & None & $\begin{array}{l}\text { Retropharyngeal } \\
\text { abscess }\end{array}$ & IIB & $\begin{array}{l}\beta \text {-Hemolytic } \\
\text { streptococci } \\
\text { and anaerobics }\end{array}$ & $\begin{array}{l}\mathrm{R} \text { cervicotomy } \\
\text { and B VATS }\end{array}$ & B VATS & 41 & $\begin{array}{l}\text { Discharge on } \\
\text { POD } 50\end{array}$ \\
\hline 14 & $69 / \mathrm{M}$ & DM, HTN, COPD & $\begin{array}{c}\text { Peritonsillar } \\
\text { abscess }\end{array}$ & 1 & $\begin{array}{l}\text { Klebsiella } \\
\text { pneumonia }\end{array}$ & $\begin{array}{l}\text { L cervicotomy and } \\
\text { transcervical } \\
\text { mediastinal } \\
\text { drainage }\end{array}$ & $\begin{array}{l}\mathrm{L} \text { cervicotomy } \\
\text { and } \mathrm{R} \text { VATS }\end{array}$ & 40 & $\begin{array}{l}\text { Discharge on } \\
\text { POD } 40\end{array}$ \\
\hline 15 & $64 / \mathrm{F}$ & DM, HTN, CAD & Acute epiglottis & IIB & None & $\begin{array}{l}\mathrm{R} \text { cervicotomy } \\
\text { and R VATS }\end{array}$ & None & 18 & $\begin{array}{l}\text { Discharge on } \\
\text { POD } 47\end{array}$ \\
\hline 16 & $66 / F$ & DM, HTN & $\begin{array}{l}\text { Retropharyngeal } \\
\text { abscess }\end{array}$ & IIB & None & $\begin{array}{l}\text { B cervicotomy } \\
\text { and B VATS }\end{array}$ & B cervicotomy & 34 & $\begin{array}{l}\text { Discharge on } \\
\text { POD } 61\end{array}$ \\
\hline 17 & $72 / F$ & DM, HTN, SAH & $\begin{array}{l}\text { Thermodilution } \\
\text { catheter } \\
\text { infection }\end{array}$ & IIB & $\begin{array}{l}\text { Klebsiella } \\
\text { pneumonia }\end{array}$ & $\begin{array}{l}R \text { cervicotomy and } \\
\text { B VATS }\end{array}$ & $\begin{array}{l}\text { R cervicotomy } \\
\text { for two times }\end{array}$ & 10 & $\begin{array}{l}\text { Discharge } \\
\text { on POD } 90\end{array}$ \\
\hline
\end{tabular}


TABLE 1. Continued

\begin{tabular}{|c|c|c|c|c|c|c|c|c|}
\hline No. Age/sex & $\begin{array}{l}\text { Systemic } \\
\text { diseases }\end{array}$ & Etiology & $\begin{array}{l}\text { Endo } \\
\text { class }\end{array}$ & Bacteriology & $\begin{array}{c}\text { Surgical } \\
\text { treatment }\end{array}$ & Reoperation & $\begin{array}{c}\text { ICU } \\
\text { stay (d) }\end{array}$ & Outcome \\
\hline $1857 / M$ & $\begin{array}{c}\text { Oral cancer, } \\
\text { panhypopituitarism } \\
\text { with steroid usage }\end{array}$ & $\begin{array}{l}\text { Odontogenic } \\
\text { abscess }\end{array}$ & I & $\begin{array}{l}\beta \text {-Hemolytic } \\
\text { streptococci }\end{array}$ & $\begin{array}{l}\text { L cervicotomy and } \\
\text { transcervical } \\
\text { mediastinal } \\
\text { drainage }\end{array}$ & None & 7 & $\begin{array}{l}\text { Discharge } \\
\text { on POD } 28\end{array}$ \\
\hline
\end{tabular}

$M$, Male; $F$, female; DM, diabetes mellitus; $H T N$, hypertension; $L C$, liver cirrhosis; $P U D$, peptic ulcer disease; $H C C$, hepatic cell carcinoma; $C O P D$, chronic obstructive pulmonary disease; $C R I$, chronic renal insufficiency; $C A D$, coronary artery disease; $C V A$, cerebrovascular accident; $S A H$, subarachnoid hemorrhage; $V A T S$, video-assisted thoracoscopic surgery; $R$, right; $L$, left; $B$, bilateral; $P O D$, postoperative day; $O P$, operation.

neck and thorax, establishing the relationship between neck infection and mediastinitis (Figure 1). Moreover, the CT scan demonstrates the extent of disease and stage evaluated by Endo's classification, ${ }^{5}$ which guided surgeons choosing the optimal operative procedures, ranging from transcervical drainage to posterolateral thoracotomy. Therefore, routine chest CT scanning was suggested for patients with deep neck infection. ${ }^{2,4-6,9,12,14,19-21}$ As in other types of necrotizing infections, intravenous broad-spectrum antibiotic therapy alone is not effective without adequate surgical drainage, extensive debridement, and excision of necrotic tissue.

Aggressive surgical drainage is essential for successful management of DNM, including cervical and mediastinal drainage. Cervical exploration and drainage, including definitive treatment of the inciting oropharyngeal or cervical infection, is considered compulsory therapy., ${ }^{2,6,9,14}$ However, because of the anatomic relationships of the cervicothoracic region, the progressive nature of DNM, and the variety of incisions available, controversy still exists as to whether a transthoracic approach for drainage and debridement is universally required and what the optimal surgical approach should be. Several approaches for mediastinal drainage have been proposed in the literature: transcervical, subxiphoid, median sternotomy, clamshell incision, posterolateral thoracotomy, video-assisted mediastinoscopy, and VATS. ${ }^{2,4,6-14,16,19,20,22-25}$

Estrera and colleagues ${ }^{2}$ described the first large series in the antibiotic era. On the basis of their own analysis, they supported transthoracic drainage for mediastinitis below the fourth thoracic vertebra posteriorly and below the carina anteriorly for persistent sepsis after cervical drainage. In
1990, Wheatley and colleagues ${ }^{14}$ condemned simple cervical drainage because their review of the literature revealed that transcervical mediastinal drainage was inadequate in $80 \%$ of patients. They preferred the combination of cervical drainage with anterior mediastinal drainage through the subxiphoid approach. Later, Marty-Ané, ${ }^{9}$ Corsten, ${ }^{4}$ Freeman, ${ }^{6}$ and their colleagues advocated aggressive mediastinal drainage via a standard thoracotomy approach as the optimum treatment for DNM, regardless of the level of mediastinal involvement. They stated that the mediastinum cannot be adequately drained via a limited approach through subxiphoid or anterior mediastinotomy and suggested the use of early thoracotomy for the best control of mediastinal sepsis. Moreover, some advocated the clamshell incision owing to excellent exposure for bilateral decortication and debridement of the entire mediastinum, including pericardiectomy. ${ }^{15}$ Although the exposure is excellent with the advantage of a 1-stage operation, it is a high-risk approach for critically ill patients with overwhelming sepsis and it exposes them to the risk of phrenic nerve palsy and sternal osteomyelitis. ${ }^{12}$ Median sternotomy also seems feasible in type I and IIA DNM but inadequate in type IIB DNM, because the approach to the posterobasal compartments of the chest cavity is difficult. ${ }^{16}$ Subsequent osteomyelitis and dehiscence of the sternum were also dreaded complications. However, a vacuum-assisted closure device may be useful, because it promotes tissue approximation and stimulates the ingrowth of granulation tissue in sternotomy. ${ }^{25}$

In 1999, Endo and colleagues ${ }^{5}$ classified DNM into types I, IIA, and IIB according to the degree of diffusion of the

TABLE 2. Comparison of patients with non-Klebsiella and Klebsiella DNM

\begin{tabular}{lccccccc}
\hline & $\begin{array}{c}\text { No. of } \\
\text { patients }\end{array}$ & $\begin{array}{c}\text { Mean } \\
\text { age } \pm \text { SD (y) }\end{array}$ & $\begin{array}{c}\text { No. of diabetic } \\
\text { patients (\%) }\end{array}$ & $\begin{array}{c}\text { No. of patients } \\
\text { with reoperation } \\
\text { or mortality (\%) }\end{array}$ & $\begin{array}{c}\text { No. of } \\
\text { patients with } \\
\text { tracheostomy (\%) }\end{array}$ & $\begin{array}{c}\text { ICU } \\
\text { stay } \pm \text { SD (d) }\end{array}$ & $\begin{array}{c}\text { Hospitalization } \\
\pm \text { SD (d) }\end{array}$ \\
\hline Klebsiella DNM & 6 & $65.2 \pm 5.2$ & $6(100)$ & $5(83)$ & $4(67)$ & $16.5 \pm 13.2$ \\
Non-Klebsiella DNM & 8 & $48.1 \pm 17.8$ & $2(25)$ & $2(25)$ & $3(38)$ & $12.1 \pm 14.8$ & $32 \pm 9.8$ \\
$P$ values & & $.04^{*}$ & $.01 \dagger$ & $.05 \dagger$ & $.29 \dagger$ & $.58^{*}$ & $.5^{*}$ \\
\hline
\end{tabular}

$S D$, Standard deviation; $I C U$, intensive care unit. ${ }^{*}$ Student $t$ test. †Fisher exact test. 
infection. They suggested that transthoracic mediastinal drainage might not always be required in type I but was always needed in type II. Because of the vigorous application of VATS in thoracic surgery worldwide since 1990, more and more authors advocate it as one of the treatments for this devastating disease. Roberts and colleagues ${ }^{26}$ first reported a case of thoracoscopic drainage as an alternative way in a patient with mediastinal abscesses resulting from esophageal perforation. In 2004, Isowa and colleagues ${ }^{7}$ reported the successful management of a patient with DNM via VATS. Furthermore, two other groups of authors reported their successful use of VATS in 4 and 9 patients with DNM and emphasized the lower degree of invasiveness and early application. ${ }^{10,24}$ Because VATS allows excellent visualization of the entire thoracic cavity, it is possible to drain mediastinal, pleural, or pericardial effusions in the course of treating DNM (Figure 2). Sometimes, single-lung ventilation was difficult or impossible in critically ill patients with DNM. In that circumstance, we performed VATS debridement and drainage with double-lung ventilation. Alternatively, we induced short-term apnea or ventilation with a small tidal volume. The above strategies made the operation possible.

On the basis of our experience, the stage and the extent of DNM, as well as the clinical condition of the patients, should be carefully pondered when operative methods are being chosen. In our country, more than half of the patients have type I DNM, possibly because Taiwan is a small island and medical service is very convenient, which might be helpful in early diagnosis. When type I DNM is noted, cervicotomy with transcervical mediastinal drainage may be sufficient. Mediastinoscopy-assisted drainage may also be helpful in this stage. ${ }^{13}$ Although most of the patients $(8 / 11,73 \%)$ with type I DNM were treated successfully by transcervical drainage without a transthoracic approach, $3(27 \%)$ of them still needed VATS reoperation later. A low threshold should exist for performing a VATS procedure even in Endo type I cases when there is even a remote concern regarding caudal extension of the septic process to or below the carina. When type IIA was noted, an additional subxiphoid approach was suggested. When applied early in type IIB, VATS may be an excellent tool. Reoperation and bilateral involvement are likely owing to both the great toxicity of DNM and the weak immunologic status of patients. VATS can play an ideal role both for initial treatment and for reoperation because of its lower degree of invasiveness. Less invasiveness and surgical trauma bring less impairment of the immunologic status and a lower inflammatory and cytokine response, ${ }^{27,28}$ which are also beneficial given the critical condition of patients with DNM. In addition, VATS has the universal advantages of minimally invasive surgery, such as little pain, better cosmesis, and faster recovery. ${ }^{10,13}$ Our policy of multidisciplinary, minimally invasive procedures achieved a low mortality rate of $16.7 \%$, which was encouraging.

The incidence of DNM is much higher in patients who are in poor physical condition owing to malnutrition, diabetes mellitus, alcoholism, drug addiction, or immunosuppression than in the general population..$^{4,9,20,23}$ Diabetes mellitus is the most common systemic disease in DNM patients in our study, with an incidence of $61.1 \%$. It has been reported that, in Taiwan, several infectious diseases in diabetic patients are most frequently caused by Klebsiella pneumoniae, including pyogenic liver abscess, empyema, meningitis, necrotizing fasciitis, and deep neck infection. ${ }^{18,29-35}$ As for
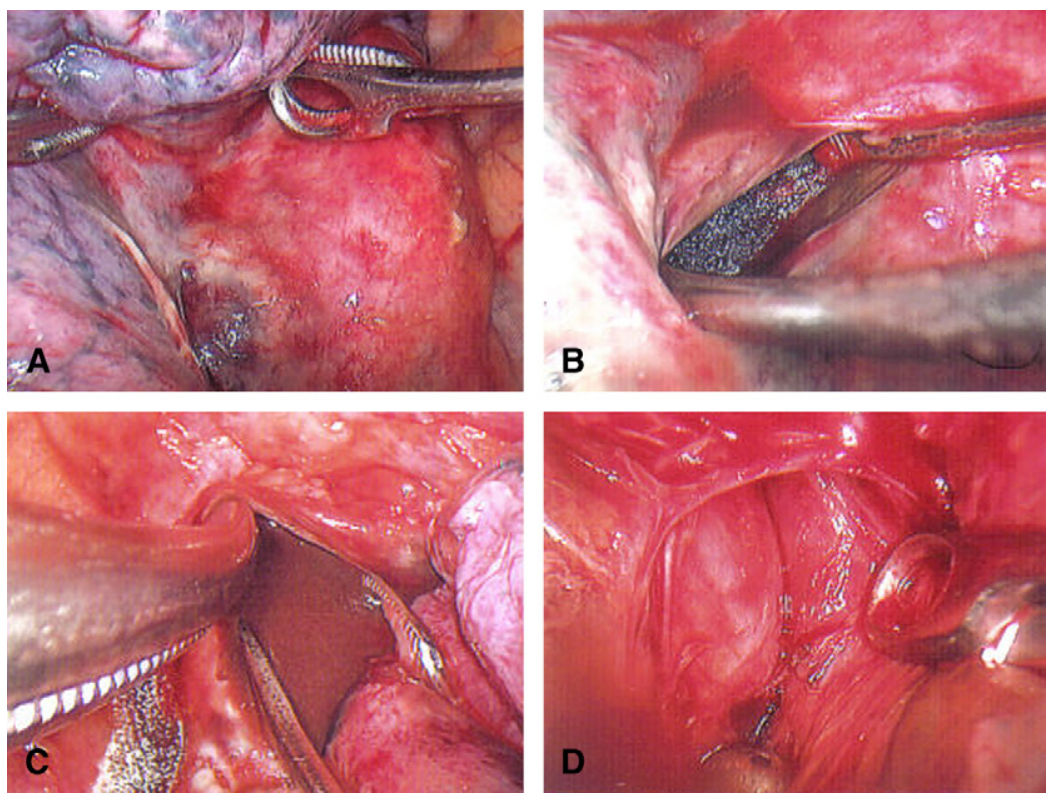

Figure 2. In case 16, during left VATS exploration, the inflamed mediastinal pleura at the para-aortic area was opened (A and B). Much purulent discharge and necrotic tissue was drained out and debrided with normal saline irrigation (C). Finally, the mediastinum was clear (D) and chest tube placement was precise with VATS. 
DNM, Klebsiella pneumoniae was also the most frequently isolated sole pathogen in our study. Previous studies revealed that the bacteriologic pattern of DNM is usually polymicrobial and most commonly noted with beta-hemolytic streptococci, ${ }^{2,4,6}$ but our study showed only $35.7 \%$ were polymicrobial. Moreover, our finding demonstrates a significant correlation between diabetes mellitus and Klebsiella pneumonia in patients with DNM $(P=.01)$. The reason for the association of Klebsiella pneumonia infection with diabetes mellitus remains unknown, but the infections caused by Klebsiella pneumonia in diabetic patients are more severe and require more aggressive intervention and repetitive drainage. ${ }^{17,30,33}$ The Klebsiella DNM in our study showed the same tendency, being associated with older patients $(P=.04)$ and a higher rate of reoperation or mortality $(P=$ $.05)$. Therefore, in clinical practice, we should be very alert about the diagnosis of DNM, especially in diabetic patients, because an even more fulminant course caused by Klebsiella pneumonia might be encountered, which requires quicker and more aggressive surgical intervention.

\section{Conclusions}

DNM remains a life-threatening infection. On the basis of experience accrued in treating 18 patients in a period of 10 years, we conclude that a laddered approach with transcervical mediastinal drainage is first justified in patients with limited disease in the upper mediastinum, but a low threshold should exist for performing early VATS. For those cases involving the lower anterior mediastinum, an additional subxiphoid approach was suggested. Cervicotomy with VATS mediastinal drainage is an excellent combination for involvement of the posterior mediastinum and pleural space. Klebsiella pneumoniae uniquely represents the most common pathogen in diabetic Taiwanese patients, leading to more complicated courses in older patients and requiring more surgical interventions than other pathogens.

\section{References}

1. Pearse HE. Mediastinitis following cervical suppuration. Ann Surg. 1938;108:588-611.

2. Estrera AS, Landay MJ, Grisham JM, Sinn DP, Platt MR. Descending necrotizing mediastinitis. Surg Gynecol Obstet. 1983;157:545-52.

3. Brunelli A, Sabbatini A, Catalini G, Fianchini A. Descending necrotizing mediastinitis: cervicotomy or thoracotomy? $J$ Thorac Cardiovasc Surg. 1996;111:485-6.

4. Corsten MJ, Shamji FM, Odell PF, Frederico JA, Laframboise GG, Reid KR, et al. Optimal treatment of descending necrotising mediastinitis. Thorax. 1997;52:702-8.

5. Endo S, Murayama F, Hasegawa T, Yamamoto S, Yamaguchi T, Sohara Y, et al. Guideline of surgical management based on diffusion of descending necrotizing mediastinitis. Jpn J Thorac Cardiovasc Surg. 1999;47:14-9.

6. Freeman RK, Vallieres E, Verrier ED, Karmy-Jones R, Wood DE. Descending necrotizing mediastinitis: an analysis of the effects of serial surgical debridement on patient mortality. J Thorac Cardiovasc Surg. 2000;119:260-7.
7. Isowa N, Yamada T, Kijima T, Hasegawa K, Chihara K. Successful thoracoscopic debridement of descending necrotizing mediastinitis. Ann Thorac Surg. 2004;77:1834-7.

8. Lavini C, Natali P, Morandi U, Dallari S, Bergamini G. Descending necrotizing mediastinitis. Diagnosis and surgical treatment. J Cardiovasc Surg (Torino). 2003;44:655-60.

9. Marty-Ané CH, Berthet JP, Alric P, Pegis JD, Rouviere P, Mary H. Management of descending necrotizing mediastinitis: an aggressive treatment for an aggressive disease. Ann Thorac Surg. 1999;68:212-7.

10. Min HK, Choi YS, Shim YM, Sohn YI, Kim J. Descending necrotizing mediastinitis: a minimally invasive approach using video-assisted thoracoscopic surgery. Ann Thorac Surg. 2004;77:306-10.

11. Mora R, Jankowska B, Catrambone U, Passali GC, Mora F, Leoncini G, et al. Descending necrotizing mediastinitis: ten years' experience. Ear Nose Throat J. 2004;83:774, 76-80.

12. Papalia E, Rena O, Oliaro A, Cavallo A, Giobbe R, Casadio C, et al. Descending necrotizing mediastinitis: surgical management. Eur J Cardiothorac Surg. 2001;20:739-42.

13. Shimizu K, Otani Y, Nakano T, Takayasu Y, Yasuoka Y, Morishita Y. Successful video-assisted mediastinoscopic drainage of descending necrotizing mediastinitis. Ann Thorac Surg. 2006;81:2279-81.

14. Wheatley MJ, Stirling MC, Kirsh MM, Gago O, Orringer MB. Descending necrotizing mediastinitis: transcervical drainage is not enough. Ann Thorac Surg. 1990;49:780-4.

15. Ris HB, Banic A, Furrer M, Caversaccio M, Cerny A, Zbaren P. Descending necrotizing mediastinitis: surgical treatment via clamshell approach. Ann Thorac Surg. 1996;62:1650-4.

16. Casanova J, Bastos P, Barreiros F, Gomes MR. Descending necrotising mediastinitis-successful treatment using a radical approach. Eur J Cardiothorac Surg. 1997;12:494-6.

17. Huang TT, Liu TC, Chen PR, Tseng FY, Yeh TH, Chen YS. Deep neck infection: analysis of 185 cases. Head Neck. 2004;26:854-60.

18. Wang LF, Kuo WR, Tsai SM, Huang KJ. Characterizations of lifethreatening deep cervical space infections: a review of one hundred ninety-six cases. Am J Otolaryngol. 2003;24:111-7.

19. Iwata T, Sekine Y, Shibuya K, Yasufuku K, Iyoda A, Iizasa T, et al. Early open thoracotomy and mediastinopleural irrigation for severe descending necrotizing mediastinitis. Eur J Cardiothorac Surg. 2005; 28:384-8.

20. Mihos P, Potaris K, Gakidis I, Papadakis D, Rallis G. Management of descending necrotizing mediastinitis. J Oral Maxillofac Surg. 2004; 62:966-72.

21. Misthos P, Katsaragakis S, Kakaris S, Theodorou D, Skottis I. Descending necrotizing anterior mediastinitis: analysis of survival and surgical treatment modalities. J Oral Maxillofac Surg. 2007;65:635-9.

22. Brunelli A, Sabbatini A, Catalini G, Fianchini A. Descending necrotizing mediastinitis. Surgical drainage and tracheostomy. Arch Otolaryngol Head Neck Surg. 1996;122:1326-9.

23. Makeieff M, Gresillon N, Berthet JP, Garrel R, Crampette L, MartyAne $\mathrm{C}$, et al. Management of descending necrotizing mediastinitis. Laryngoscope. 2004;114:772-5.

24. Son HS, Cho JH, Park SM, Sun K, Kim KT, Lee SH. Management of descending necrotizing mediastinitis using minimally invasive videoassisted thoracoscopic surgery. Surg Laparosc Endosc Percutan Tech. 2006;16:379-82.

25. Gorlitzer M, Grabenwoeger M, Meinhart J, Swoboda H, Oczenski W, Fiegl N, et al. Descending necrotizing mediastinitis treated with rapid sternotomy followed by vacuum-assisted therapy. Ann Thorac Surg. 2007;83:393-6

26. Roberts JR, Smythe WR, Weber RW, Lanutti M, Rosengard BR, Kaiser LR. Thoracoscopic management of descending necrotizing mediastinitis. Chest. 1997;112:850-4.

27. Novitsky YW, Litwin DE, Callery MP. The net immunologic advantage of laparoscopic surgery. Surg Endosc. 2004;18:1411-9.

28. Ng CS, Whelan RL, Lacy AM, Yim AP. Is minimal access surgery for cancer associated with immunologic benefits? World J Surg. 2005;29: 975-81.

29. Chang CC, Lu CH, Huang CR, Chuang YC, Tsai NW, Chen SF, et al. Culture-proven bacterial meningitis in elderly patients in southern Taiwan: clinical characteristics and prognostic factors. Acta Neurol Taiwan. 2006;15:84-91. 
30. Chang CM, Lu FH, Guo HR, Ko WC. Klebsiella pneumoniae fascial space infections of the head and neck in Taiwan: emphasis on diabetic patients and repetitive infections. J Infect. 2005;50:34-40.

31. Chen KY, Hsueh PR, Liaw YS, Yang PC, Luh KT. A 10-year experience with bacteriology of acute thoracic empyema: emphasis on Klebsiella pneumoniae in patients with diabetes mellitus. Chest. 2000;117:1685-9.

32. Cheng DL, Liu YC, Yen MY, Liu CY, Wang RS. Septic metastatic lesions of pyogenic liver abscess. Their association with Klebsiella pneumoniae bacteremia in diabetic patients. Arch Intern Med. 1991;151:1557-9.
33. Huang TT, Tseng FY, Liu TC, Hsu CJ, Chen YS. Deep neck infection in diabetic patients: comparison of clinical picture and outcomes with nondiabetic patients. Otolaryngol Head Neck Surg. 2005;132:943-7.

34. Liu YM, Chi CY, Ho MW, Chen CM, Liao WC, Ho CM, et al. Microbiology and factors affecting mortality in necrotizing fasciitis. $J$ Microbiol Immunol Infect. 2005;38:430-5.

35. Wang JH, Liu YC, Lee SS, Yen MY, Chen YS, Wang JH, et al. Primary liver abscess due to Klebsiella pneumoniae in Taiwan. Clin Infect Dis. 1998;26:1434-8. 